\title{
Apical Extrusion of Debris and Irrigant Using XP-Endo Finisher, EndoActivator, Passive Ultrasonic Irrigation or Syringe Irrigation
}

\author{
XP-Endo Finisher Eğesi, EndoActivator, Pasif Ultrasonik \\ Irrigasyon veya İğne Irrigasyonu Sırasında Meydana Gelen \\ Debris ve Irrigant Ekstrüzyonunun Değerlendirilmesi \\ (1) Evren Sarıyılmaz ${ }^{1}$, (1) Cangül Keskin ${ }^{2}$ \\ 1Ordu University Faculty of Dentistry, Department of Endodontics, Ordu, Turkey \\ 20ndokuz Mayıs University Faculty of Dentistry, Department of Endodontics, Samsun, Turkey
}

Keywords

XP-Endo Finisher, passive ultrasonic irrigation, sonic irrigation, apical extrusion

Anahtar Kelimeler

XP-Endo Finisher, pasif ultrasonik irrigasyon, sonik irrigasyon, apikal ekstrüzyon

Received/Geliş Tarihi : 27.04.2017

Accepted/Kabul Tarihi : 18.06.2017

doi:10.4274/meandros.24008

Address for Correspondence/Yazışma Adresi: Evren Sarıyılmaz MD,

Ordu University Faculty of Dentistry, Department of Endodontics, Ordu, Turkey

Phone: +90 5327078723

E-mail : evrensariyilmaz@yahoo.com

ORCID ID: orcid.org/0000-0003-1711-7056

(C) Meandros Medical and Dental Journal, Published by Galenos Publishing House.

This is article distributed under the terms of the Creative Commons Attribution NonCommercial 4.0

International Licence (CC BY-NC 4.0).

\begin{abstract}
Objective: Extrusion of irrigant and debris into the periapical tissues is a potential risk for flare-ups during root canal treatment. The aim of this study was to evaluate the apically extruded debris and sodium hypochlorite during XP-Endo Finisher (XP-Endo) file use and compare with final irrigation techniques. The tested null hypothesis in this study was that there was no difference among the irrigation techniques.

Materials and Methods: An agar gel model was prepared for 80 extracted single rooted human mandibular premolar teeth, which were prepared up to the apical size of \#40. The samples were divided into four groups according to the final irrigation regime: conventional syringe irrigation, XP-Endo, passive ultrasonic irrigation (PUI), and EndoActivator (EA). The test apparatus was weighed before and after the experiment, and the amount of apically extruded debris and irrigant was calculated.

Results: There was minimal irrigant and debris extrusion in all groups. No significant difference among the tested groups was detected ( $p>0.05$ ).

Conclusion: Using the PUI, XP-Endo file, or EA according to the manufacturers' instruction does not increase the extrusion risk.

Öz

Amaç: Kanal tedavisi esnasında irrigantların ve debrisin periapikal dokulara taşması akut alevlenme açısından potansiyel bir risk teşkil etmektedir. Bu çalışmanın amacı XP-Endo Finisher (XP-Endo) kullanımı esnasında apikalden taşan debrisi ve sodyum hipokloriti değerlendirmek ve final irrigasyon teknikleri ile karşılaştırmaktır. Çalışmanın sıfır hipotezi, test edilen sistemler arasında fark olmadığıdır.

Gereç ve Yöntemler: Bir agar jel model, apikal boyutları 40 numaraya kadar prepare edilmiş 80 adet çekilmiş tek köklü insan mandibular premolar dişi kullanılarak hazırlandı. Örnekler final irrigasyon protokolüne göre dört gruba ayrıldı: Geleneksel iğne irrigasyonu, XP-Endo, EndoActivator (EA) ve pasif ultrasonik irrigasyon (PUI). Test düzeneği deneyden önce ve sonra tartıldı ve apikalden taşan debris ve irrigant hesaplandı.
\end{abstract}


Bulgular: Her grupta minimal irrigant ve debris ekstrüzyonu saptandı. Test edilen gruplar arasında anlamlı fark bulunamadı $(p>0,05)$. Sonuç: PUI, XP-Endo ve EA üretici firma talimatlarına uyarak kullanıldığında apikal ekstrüzyon riskini artırmamaktadır.

\section{Introduction}

Endodontic treatment utilizes irrigants to achieve chemomechanical preparation to remove tissue remnants, debris, microorganisms and their byproducts from the root canal systems (1). Extrusion of irrigants, dentinal chips, debris, and microorganisms to periapical tissues is inevitable during root canal treatment. These extruded substances may lead to inflammation, postoperative pain, and/or delay in periapical healing $(2,3)$. Many irrigation systems have been developed to deliver and activate irrigants during endodontic treatment. Besides these objectives, ensuring safety during irrigation activation should be considered while using these systems (4).

EndoActivator (EA) (Dentsply, York, PA, USA), which has a handpiece and various disposable polymer activator tips (yellow 15/02, red 25/04, blue 35/04) that do not cut dentin, is a sonic irrigation activation system (5). EA is recommended for irrigant agitation, after flushing root canals using conventional syringe irrigation (SI), as final step of chemomechanical root canal preparation (6). The polymer tips, which should passively fit in the root canal, are activated by a battery-operated handpiece at 10000 cycles/ min for 30-60 seconds. EA has been reported as a safe irrigation agitation procedure when compared to manual activation (4). XP-Endo Finisher (XP-Endo) (FKG Dentaire SA, La Chaux-de-Fonds, Switzerland) was designed as a final canal irrigation protocol to enhance cleaning. XP-Endo is a non-tapered instrument (size $\# 25$ ) and was developed to both respect the original root canal anatomy and effectively clean those irregular areas due to its reputed increased flexibility and ability to expand to adapt to the root canal three dimensionally (7). Its ability to remove hard tissue debris and smear layer effectively has been reported in previous studies $(7,8)$. However, to our knowledge, there is no study on the amount of apically extruded debris and irrigant during the use of the XP-Endo.

Several in vitro techniques have been used to calculate the amount of apical extrusion of irrigants and debris $(9,10)$. Most studies utilized the empty tube model, but this model does not simulate in vivo clinical conditions because, unlike periodontal ligament, empty tube does not provide a back pressure $(9,10)$. Lu et al. (11) developed a $1.5 \%$ agar gel model to provide back pressure for apically extruded materials and reported that the model simulates clinical conditions more accurately than the empty tube model. The aim of this study was to compare the amount of apically extruded debris and irrigant during the use of the XP-Endo file, EA, passive ultrasonic irrigation (PUI), and SI. The null hypothesis that tested in this study was that there is no difference among these final disinfection steps.

\section{Materials and Methods}

The study protocol of this study was approved by the Ordu University Clinical Researches Ethics Committee (2016/70). This study was performed in accordance with the World Medical Association Declaration of Helsinki. Written informed consent was obtained from all participants. Sample size calculation revealed that a minimum 12 specimens per group would suffice to show a $5 \%$ difference in amount of apically extruded debris with a power of $90 \%$. Eighty freshly extracted human mandibular premolar teeth that fulfilled following criteria were selected: single straight root, fully formed apex, no resorption, and no calcified root canals. The canal curvatures, which were determined according to Schneider's method, were less than $10^{\circ}(12)$. The root lengths were standardized as $14 \mathrm{~mm}(14 \pm 0.85 \mathrm{~mm})$ using sterile diamond disks under water-cooling by removing the crown. A \#20 broach was used to extirpate the pulp tissue. The working length (WL) of each root canal was determined to be $1 \mathrm{~mm}$ short of the length of a $\# 10 \mathrm{~K}$ file (VDW GmbH, Munich, Germany) that was visible at the apical foramen. The root canals were prepared with the Reciproc system up to the file R40 under copious $5.25 \%$ sodium hypochlorite $(\mathrm{NaOCl})$ irrigation $(5 \mathrm{~mL})$. Canal patency was maintained by inserting a \#10 K-file $1 \mathrm{~mm}$ beyond the apical foramen. Following the completion of root canal mechanical preparation, the canals were flushed with $2 \mathrm{~mL}$ distilled water and $2.5 \mathrm{~mL}$ of $17 \%$ ethylenediaminetetraacetic acid, respectively. The specimens were numbered and then weighed three times using an analytical balance with 
10-4 g accuracy (Precisa XB 220A, Precisa Instruments, Dietikon, Switzerland).

An agar gel model was prepared as described by Lu et al. (11). A 1.5\% agar solution was prepared and then injected into Eppendorf tubes, which were inverted for gel to seal the cling film-coated root surfaces. Following the congelation of agar, the test apparatus was reweighed three times. The weight of the apparatus without the specimens, which was recorded as the initial weight, was calculated by subtracting the specimen weight from the test apparatus's weight. The specimens were randomly divided into four groups as follows $(n=20)$ : SI (group 1), XP-Endo (group 2), EA (group 3), and PUI (group 4).

Group 1: SI. The tip of the 30-gauge side-vented needle (Ultradent, South Jordan, UT, USA) was placed $2 \mathrm{~mm}$ short of the WL, and $5.25 \%$ of $\mathrm{NaOCl}$ solution was delivered passively at a rate of $6 \mathrm{~mL} /$ minute, moving with the amplitude of $2 \mathrm{~mm}$ for 60 seconds. For WL control, a stopper was placed on the needle.

Group 2: XP-Endo. The instrument was placed in a torque-controlled endodontic motor (VDW Gold, Munich, Germany), cooled down (Chloraethyl, Dr. Georg Henning $\mathrm{GmbH}$, Germany), and then removed from the plastic tube by applying a slight lateral movement. The XP-Endo file was inserted into the root canal, which was irrigated with $6 \mathrm{~mL}$ of $5.25 \% \mathrm{NaOCl}$ without rotation. The instrument was operated at 800 rpm speed and $1 \mathrm{~N} . \mathrm{cm}$ torque value for 60 seconds with vertical movements of 7-8 $\mathrm{mm}$ to the full $\mathrm{WL}$, which was recommendation of the manufacturer.

Group 3: EA. The canals were irrigated $6 \mathrm{~mL}$ of $5.25 \% \mathrm{NaOCl}$ using a 30 -gauge side-vented needle and then 25/04 polymer tip, which mounted on EA device, was inserted into the $\mathrm{NaOCl}$-filled root canal ( $2 \mathrm{~mm}$ shorter then $\mathrm{WL}$ ). The device was activated at 10,000 cycles per minute with vertical strokes with the amplitude of $2 \mathrm{~mm}$ for 60 seconds.
Group 4: PUI. The canals were irrigated $2 \mathrm{~mL}$ of $5.25 \% \mathrm{NaOCl}$ using a 30-gauge side-vented needle. Then it was ultrasonically activated with a 15.02 ultrasonic tip (Irrisafe) mounted on a piezoelectric ultrasonic unit with the power setting at $10 \%$. The tip was placed $2 \mathrm{~mm}$ short of the WL and operated with the amplitude of $2 \mathrm{~mm}$ for 20 seconds without touching the root canal walls. The root canals were flushed with $2 \mathrm{~mL}$ of $5.25 \% \mathrm{NaOCl}$ then it was ultrasonically activated for 20 seconds again. $\mathrm{NaOCl}$ was activated by a total of three cycles of 20 seconds.

One experienced endodontist (C.K.) performed all procedures. During the experiment, the test apparatus was secured in an opaque glass vial to prevent any movement and contact of fingertips. The tooth was removed from the Eppendorf tube. The test apparatus with extruded irrigant and debris was weighed again. The weight of the extruded debris and irrigant was calculated by subtracting the initial weight from the final weight. All measurements were made three times, and the mean values were calculated. Weight measurements and analysis were performed by one clinician (E.S.) who was blinded to the study groups.

\section{Statistical Analysis}

SPSS 21.0 (SPSS Inc., Chicago, IL, USA) was used for statistical analysis. The normality of the data distribution was confirmed with the Shapiro-Wilk test, and the data was analysed by One-Way Analysis of Variance and Bonferronni post-hoc test with the level of significance of $95 \%$.

\section{Results}

The standard deviation and median values of the weighed apically extruded irrigant and debris of each experimental group are presented in Table 1. Based on the statistical analysis, no significant differences were found among the experimental groups $(p>0.05)$.

\begin{tabular}{|l|l|l|l|l|}
\hline Table 1. The mean mass of extruded debris and irrigant (g) \\
\hline & Mean value (SD) & Minimum & Maximum & $\mathbf{n}$ \\
\hline Group 1 (SI) & $385.10^{-5}\left(9.10^{-4}\right)$ & $20.10^{-5}$ & $901.10^{-5}$ & 20 \\
\hline Group 2 (XP-Endo) & $581.10^{-5}\left(6.10^{-4}\right)$ & $30.10^{-5}$ & $673.10^{-5}$ & 20 \\
\hline Group 3 (EA) & $579.10^{-5}\left(8.10^{-4}\right)$ & $60.10^{-5}$ & $700.10^{-5}$ & 20 \\
\hline Group 4 (PUI) & $429.10^{-5}\left(13.10^{-4}\right)$ & $80.10^{-5}$ & $690.10^{-5}$ & 20 \\
\hline SD: Standard deviation, SI: Syringe irrigation, XP-Endo: XP-Endo Finisher, EA: EndoActivator, PUI: Passive ultrasonic irrigation \\
\hline
\end{tabular}




\section{Discussion}

Irrigation is an indispensable phase of root canal treatment that is necessary for disinfection, lubrication, and removal of inorganic and organic tissue remnants from the root canal system due to the solutions' chemical and flushing effects (1). SI is the most widely used irrigation method because of the technique's simple usage manner, which provides needle depth and irrigant volume control (13). However, previous studies revealed that conventional $\mathrm{SI}$ is usually inadequate to achieve these goals (14). Several irrigation devices, instruments, and methods were introduced to overcome the limitations of SI (15). The common aim of these irrigation devices is to clean the root canal system more effectively by enhancing the irrigation solution's flow and distribution within the irregularities of the root canal system (16). The results of this study revealed that apical irrigant and debris extrusion occurred regardless of the final irrigation regime used, and no significant difference was observed among the SI, PUI, XP-Endo, and EA. Therefore, the null hypothesis was accepted. The amount of extruded debris produced during PUI or EA activation was investigated by many studies; however, to the authors' knowledge, there has not yet been a study regarding the amount of apically extruded debris and irrigant produced during the use of the XPEndo file.

XP-Endo is a novel NiTi file that is recommended for the removal of debris, intracanal medication, and residual obturation materials from root canals. The $\mathrm{XP}$-Endo has a unique characteristic which allows the file to be straight in the Martensitic phase at the room temperature; however, the phase and the shape of file change when inserted into the root canal to adapt to the three-dimensional root canal anatomy to access and clean the irregularities of root canals (7). According to the results of this study, the supplementary use of the XP-Endo file does not increase the risk of extrusion and could be suggested as a safe supplementary method.

Ultrasonic devices oscillate files at $25-30 \mathrm{kHz}$, producing nodes and antinodes along the file, whereas sonic devices such as EA operate at lower frequencies of about 1000 to $6000 \mathrm{~Hz}$, so only one node and antinode occur near the tip $(17,18)$. In EA, the irrigant's streaming velocity is lower when compared with ultrasonics (17). However, sonic irrigation produces higher amplitude and tip movement (18). In the present study, no significant difference was detected between EA and PUI. The results of this study are in line with a previous study that reported no significant association between the irrigation technique (PUI, EA, and $\mathrm{SI}$ ) and the apically extruded material, although there were methodological differences between these studies regarding the test models (19). The present study utilized the test apparatus described by Lu et al. (11) to simulate the back pressure of periapical tissues. In clinical conditions, the presence of periapical structures and granulation tissues might provide resistance to apically extruded irrigant and debris (20). The density of $1.5 \%$ agar gel is $1045 \mathrm{~kg}$ 3 , whereas the density of human periapical tissues is $1000-1100 \mathrm{~kg}-3$. Because of this similarity, the agar gel model was used in the present study to represent clinical situations better (11). Extruded irrigant was not distinguished from the debris because extruded irrigant can also trigger flare-up and provoke foreign body reactions (21).

The use of $\mathrm{NaOCl}$ might cause the precipitation of sodium crystals and interfere with the amount of apically extruded debris. This is why previous apical extrusion studies used distilled water as an irrigant $(22,23)$. Tanalp and Güngör (24) stated in their literature review that the use of routinely used irrigation solutions in apical extrusion studies seems logical to reflect clinical conditions. In the present study, $6 \mathrm{~mL}$ of $5.25 \% \mathrm{NaOCl}$ was used for the irrigation of the specimens of each experimental group to standardize the amount of irrigation solutions.

\section{Study Limitations}

All the factors could not be standardized in the present study since the microhardness of experimented teeth might also affect the amount of apically extruded material, which presents a limitation to the present study (24).

\section{Conclusion}

Within the limitations of this study, supplementary use of the XP-Endo file, PUI, or EA do not increase the risk of irrigant extrusion beyond the apex. Further clinical studies on postoperative pain and flare-up incidences following the use of this file are needed. 


\section{Ethics}

Ethics Committee Approval: The study protocol of this study was approved by the Ordu University Clinical Researches Ethics Committee (2016/70).

Informed Consent: Written informed consent was obtained from all participants.

Peer-review: Externally peer-reviewed.

\section{Authorship Contributions}

Concept: E.S., C.K., Design: E.S., C.K., Data Collection

or Processing: E.S., Analysis or Interpretation: C.K., Literature Search: E.S., Writing: E.S., C.K.

Conflict of Interest: No conflict of interest was declared by the authors.

Financial Disclosure: The authors declared that this study received no financial support.

\section{References}

1. Van Der Sluis Lw, Verhaagen B, Macedo R, Versluis M. The role of irrigation in endodontics. In: Giovanni Olivi, Roeland De Moor, Enrico DiVito. Lasers in Endodontics. Swidzerland: Springer International Publishing, 2016; 45-69.

2. Seltzer S, Naidorf IJ. Flare-ups in endodontics: I. Etiological factors. J Endod 1985; 11: 472-8.

3. Seltzer S, Naidorf IJ. Flare-ups in endodontics: II. Therapeutic measures. J Endod 1985; 11: 559-67.

4. Desai P, Himel V. Comparative safety of various intracanal irrigation systems. J Endod 2009; 35: 545-9.

5. Uroz-Torres D, González-Rodríguez MP, Ferrer-Luque CM. Effectiveness of the EndoActivator System in removing the smear layer after root canal instrumentation. J Endod 2010; 36: 308-11.

6. Ruddle CJ. Endodontic disinfection: tsunami irrigation. Endodontic Practice 2008; 11: 7-15.

7. Leoni GB, Versiani MA, Silva-Sousa YT, Bruniera JF, Pécora $J D$, Sousa-Neto MD. Ex vivo evaluation of four final irrigation protocols on the removal of hard-tissue debris from the mesial root canal system of mandibular first molars. Int Endod J 2016; 50: 398-406.

8. Elnaghy AM, Mandorah A, Elsaka SE. Effectiveness of XP-endo Finisher, EndoActivator, and File agitation on debris and smear layer removal in curved root canals: a comparative study. Odontology 2017; 105: 178-83.

9. Myers GL, Montgomery S. A comparison of weights of debris extruded apically by conventional filing and Canal Master techniques. J Endod 1991; 17: 275-9.

10. Üstün $Y$, Çanakçi BC, Dinçer AN, Er O, Düzgün S. Evaluation of apically extruded debris associated with several $\mathrm{Ni}$-Ti systems. Int Endod J 2015; 48: 701-4.
11. Lu Y, Wang R, Zhang L, Li HL, Zheng QH, Zhou XD, et al. Apically extruded debris and irrigant with two Ni-Ti systems and hand files when removing root fillings: a laboratory study. Int Endod J 2013; 46: 1125-30.

12. Schneider SW. A comparison of canal preparations in straight and curved root canals. Oral Surg Oral Med Oral Pathol 1971, 32: 271-5.

13. Ram Z. Effectiveness of root canal irrigation. Oral Surg Oral Med Oral Pathol 1977; 44: 306-12.

14. Thomas AR, Velmurugan N, Smita S, Jothilatha S. Comparative evaluation of canal isthmus debridement efficacy of modified EndoVac technique with different irrigation systems. J Endod 2014; 40: 1676-80.

15. Haapasalo M, Shen Y, Wang Z, Gao Y. Irrigation in endodontics. Br Dent J 2014; 216: 299-303.

16. Gu LS, Kim JR, Ling J, Choi KK, Pashley DH, Tay FR. Review of contemporary irrigant agitation techniques and devices. J Endod 2009; 35: 791-804.

17. van der Sluis LW, Versluis M, Wu MK, Wesselink PR. Passive ultrasonic irrigation of the root canal: a review of the literature. Int Endod J 2007; 40: 415-26.

18. Walmsley $A D$, Lumley PJ, Laird WR. Oscillatory pattern of sonically powered endodontic files. Int Endod J 1989; 22: 12532.

19. Rodríguez-Figueroa C, McClanahan SB, Bowles WR. Spectrophotometric determination of irrigant extrusion using passive ultrasonic irrigation, EndoActivator, or syringe irrigation. J Endod 2014; 40: 1622-6.

20. Altundasar E, Nagas E, Uyanik O, Serper A. Debris and irrigant extrusion potential of 2 rotary systems and irrigation needles. Oral Surg Oral Med Oral Pathol Oral Radiol Endod 2011; 112: e31-5.

21. Iqbal M, Kurtz E, Kohli M. Incidence and factors related to flareups in a graduate endodontic programme. Int Endod J 2009; 42: 99-104.

22. Topçuoğlu HS, Akt A, Tuncay Ö, Dinçer AN, Düzgün S, Topçuoğlu G. Evaluation of debris extruded apically during the removal of root canal filling material using ProTaper, D-RaCe, and R-Endo rotary nickel-titanium retreatment instruments and hand files. J Endod 2014; 40: 2066-9.

23. Çanakçi BC, Er O, Dincer A. Do the Sealer Solvents Used Affect Apically Extruded Debris in Retreatment? J Endod 2015; 41: 1507-9.

24. Tanalp J, Güngör T. Apical extrusion of debris: a literature review of an inherent occurrence during root canal treatment. Int Endod J 2014; 47: 211-21. 